\title{
KEBIJAKAN BISNIS ISLAMI DAN ASPEK PERPAJAKAN DALAM KEPEMILIKAN NPWP PRIBADI
}

\author{
Jeni Susyanti \\ Fakultas Ekonomi Universitas Islam Malang \\ Jl. MT Haryono 193 Malang. Tilp 0341-571996 \\ Kantor Konsultan Pajak AD Consulting \\ Jl. Kapuas 22 Malang, Tilp.0341- 494761, 498993
}

\begin{abstract}
Islam requires to look for sustenance and emphasizes the aspects of halal, both in terms of the acquisition and utilization. Islamic business policy implemented to uphold truth and justice, has the obligation to submit the mandate and principled amar ma'ruf nahi munkar. Application of sharia law is enforced during the course of its business.Mandatory contributions from business people support the sustainability of a government in society with taxes. A tax-file number (NPWP, Nomor Pokok Wajib Pajak) was actually a duty of every individual, whether an individual who carries on business or independent status or employees in line Undang-undang No. 28 tahun 2007 on General Provisions and procedures of Taxation and Undang-undang No.36 tahun 2008 on Income Tax
\end{abstract}

Keyword: Islamic Business Policies, a tax-file number (NPWP, Nomor Pokok Wajib Pajak)

Menjalankan kegiatan bisnis tidak akan pernah lepas dari tantangan dan hambatan, baik menyangkut permodalan, sumber daya manusia, pemasaran, perizinan, maupun kewajiban perpajakan. Dalam mengatasi tantangan tersebut harus diterapkan manajemen yang professional, memiliki kewajiban menegakkan kebenaran dan keadilan, memiliki kewajiban menyampaikan amanah dan berprinsip amar ma'ruf nahi munkar. Dimana segala tindakan hendaknya dilandasi motivasi untuk memperoleh keridhaan Allah dengan orientasi pada kebahagiaan akhirat, tanpa melupakan kebahagiaan duniawi. Aplikasinya adalah ditegakkan hukum syari'ah pada saat menjalankan kegiatan bisnis.

Dalam menjalankan bisnis di Indonesia sesuai dengan ketentuan umum dan tata cara perpajakan yang berlaku, setiap perusahaan yang didirikan di Indonesia atau melaksanakan kegiatan di Indonesia merupakan wajib pajak. Wajib pajak perusahaan dituntut untuk melakukan kewajiban perpajakan, selain tugasnya 
menjalankan self assessment, wajib pajak juga berkewajiban memotong dan memungut pajak.

Pengusaha menurut UU Nomor 28 tahun 2007 tentang Ketentuan Umum dan Tata Cara Perpajakan (KUP) adalah orang pribadi atau badan dalam bentuk apapun yang dalam kegiatan usaha atau pekerjaannya menghasilkan barang, mengimpor barang, mengekspor barang, melakukan usaha perdagangan, memanfaatkan barang tidak berwujud dari luar daerah pabean, melakukan usaha jasa, atau memanfaatkan jasa dari luar daerah pabean.

Sesuai ketentuan pasal 2 Undang-undang Nomor 28 Tahun 2007 (UU KUP) beserta penjelasannya, orang pribadi wajib ber-NPWP apabila telah memenuhi syarat subyektif dan obyektif. Yang dimaksud dengan syarat subyektif disini adalah persyaratan subyektif sebagaimana disebutkan dalam pasal 2 Undang-undang Nomor 7 tahun 1983 sebagaimana telah dirubah dengan Undangundang Nomor 36 tahun 2008 (UU PPh). Dalam hal ini orang pribadi dianggap memenuhi syarat subyektif bila berstatus sebagai subyek pajak Indonesia atau Subyek Pajak Dalam Negeri. Sedangkan syarat Obyektif disini merupakan persyaratan bagi subyek pajak yang menerima atau memperoleh penghasilan atau diwajibkan untuk melakukan pemotongan/ pemungutan sesuai dengan ketentuan Undang-undang Pajak Penghasilan. Sehingga syarat obyektif dapat dilihat dari dua sudut pandang, yaitu dari sisi penerima penghasilan dan dari sisi pemberi penghasilan. Kemudian mengenai saatnya ber-NPWP bagi orang pribadi, diatur dalam Peraturan Menteri Keuangan Nomor: 20/PMK.03/2008. Dalam peraturan tersebut dinyatakan bahwa bagi orang pribadi yang melakukan kegiatan usaha dan atau pekerjaan bebas wajib ber-NPWP paling lambat satu bulan setelah saat usaha mulai dijalankan.

\section{KEBIJAKAN BISNIS ISLAMI}

Bisnis dengan segala macam bentuknya terjadi dalam kehidupan, bisnis adalah suatu aktivitas yang mengarahkan pada peningkatan nilai tambah melalui proses penyerahan jasa, perdagangan atau pengolahan barang (produksi). Suatu organisasi/pelaku bisnis akan melakukan aktivitas bisnis dalam bentuk: memproduksi dan atau mendistribusikan barang dan/atau jasa, mencari profit, dan 
mencoba memuaskan konsumen. Memproduksi barang dan jasa yang tidak merusak bagi diri sendiri dan orang banyak, mencari profit dengan cara yang benar dan tidak menyalahi aturan yang telah ditentukan dan memuaskan konsumen dengan pelayanan yang sebaik-baiknya.

Dalam melaksanakan kegiatan muamalah, secara umum tugas kekhalifahan manusia adalah tugas mewujudkan kemakmuran dan kesejahteraan dalam hidup dan kehidupan, serta tugas pengabdian atau ibadah dalam arti yang luas sebagaimana rti dari ayat dalam Al Qur'an berikut ini:

"Manusia diciptakan Allah agar berfungsi sebagai penguasa (khalifah) di bumi” (QS 6:165).

"Dan tidaklah Kami mengutus kamu melainkan untuk (menjadi) rahmat bagi semesta alam.”(al-Anbiyaa':107)

Skinner (1992) mendefinisikan bisnis sebagai pertukaran barang, jasa, atau uang yang saling menguntungkan atau memberi manfaat. Sedangkan Yusanto dan Widjajakusuma (2002) memaparkan bisnis Islami sebagai serangkaian aktivitas bisnis dalam berbagai bentuknya yang tidak dibatasi jumlah (kuantitas) kepemilikan hartanya (barang/jasa) termasuk profitnya, Namun dibatasi dalam cara perolehan dan pendayagunaan hartanya (ada aturan halal dan haram).

Islam mewajibkan setiap muslim untuk bekerja (mencari rezeki) dan menekankan pada aspek kehalalan, baik dari sisi perolehan maupun pendayagunaan seperti terkandung berikut ini: "Dialah yang menjadikan bumi ini mudah bagi kamu, maka berjalanlah di segala penjurunya dan makanlah sebagaian dari rejeki-Nya....” (al-Mulk:15); "Sesungguhnya, kami telah menempatkan kamu sekalian di bumi dan kami adakan bagimu dimuka bumi itu (sumber-sumber) penghidupan....” (al-A'raaf:10); “...Dia (Allah) telah menciptakan kalian dari bumi (tanah) dan menjadikan kamu pemakmurnya...”(Huud:61)

Bagi pebisnis muslim tantangan terbesar adalah bagaimana menjalankan bisnis dengan tetap berpegang pada nilai-nilai Islam pada masa globalisasi ini, walaupun masih cukup banyak peluang terbuka bagi pebisnis muslim yang mencoba untuk sukses tanpa harus melanggar syari'at.

“ sesungguhnya, setelah kesulitan itu ada kemudahan.” (Alam Nasyrah:6). 
Dalam mengatasi tantangan tersebut harus diterapkan kebijakan bisnis Islami dengan manajemen yang professional. Kebijakan bisnis tersebut dijalankan dengan memiliki kewajiban menegakkan kebenaran dan keadilan, memiliki kewajiban menyampaikan amanah dan berprinsip amar ma'ruf nahi munkar. Dimana segala tindakan hendaknya dilandasi motivasi untuk memperoleh keridhaan Allah dengan orientasi pada kebahagiaan akhirat, tanpa melupakan kebahagiaan duniawi. Aplikasinya adalah ditegakkan hukum syari'ah pada saat menjalankan kegiatan bisnisnya.

Profesionalisme dalam bisnis Islami menurut Yusanto dan Widjajakusuma (2002) dicirikan oleh tiga hal, pertama cakap atau ahli dalam bidang pekerjaan yang dilakukan (kafa'ah) yang diperoleh melalui pendidikan, pelatihan, dan pengalaman. Kedua memiliki semangat atau etos kerja yang tinggi (himmatul'amal) yang diraih dengan jalan menjadikan motivasi ibadah sebagai pendorong utama dalam bekerja disamping motivasi ingin mendapatkan penghargaan (reward) dan menghindari hukuman (punishment). Ketiga, bertanggung jawab dan terpercaya dalam menjalankan setiap tugas atau kewajibannya (amanah) yang diperoleh dengan menjadikan tauhid sebagai unsur pengontrol utama tingkah laku.

Bisnis yang dijalankan dengan niat dan cara yang benar adalah ibadah yang besar sekali pahalanya. Kalau kita mau sukses, kunci pertama adalah jujur, dengan bermodalkan kejujuran orang akan percaya pada kita. Kedua adalah professional, kita harus cakap sehingga siapapun yang memerlukan kita merasa puas dengan yang kita kerjakan. Ketiga, inovatif artinya kita harus mampu menciptakan sesuatu yang baru, jangan hanya menjiplak atau meniru yang sudah ada (Gymnastiar dalam Deden, 2002). Berkaitan dengan bisnis, Al- Qur'an (dalam yusanto dan Widjajakusuma, 2002) sebagai wahyu Allah menunjukkan sejumlah hal penting, diantaranya sebagai berikut: (1) Seruan pengadaan pangan berkualitas, sebagaimana dalam Al Baqoroh: Hai sekalian manusia, makanlah yang halal lagi baik dari apa yang terdapat dibumi dan janganlah kamu mengikuti langkah-langkah setan....”;(2) Seruan pengadaan pakaian berkualitas: "Hai anak Adam, sesungguhnya kami telah menurunkan kepadamu pakaian untuk menutupi auratmu dan pakaian indah untuk perhiasan.....” (al-A'raaf:26); (3) Anjuran pengadaan jasa transportasi: "Dan ia (binatang itu) mengangkut beban- 
bebanmu ke suatu negeri yang kamu tidak sanggup sampai kepadanya melainkan dengan kesukaran-kesukaran (yang memayahkan) diri. Sesungguhnya, Allah benar-benar Maha Pengasih lagu Maha Penyayang, dan (Dia telah menciptakan) kuda, bighal, dan khimar agar kamu menungganginya....”(an-Nahl:7-8); (4) Anjuran pengadaan jasa perdagangan: “....Allah telah menghalalkan jual beli dan mengharamkan riba..." (al-Baqarah:275) dan (5) Dorongan aktivitas pencerdasan umat: "Tidak sepatutnya bagi orang-orang mukmin itu pergi semuanya (ke medan perang). Mengapa tidak pergi dari tiap-tiap golongan diantara mereka beberapa orang untuk memperdalam pengetahuan mereka tentang agama dan untuk membetri peringatan kepada kaumnya apabila mereka telah kembali kepadanya, supaya mereka itu dapat menjaga dirinya." (at-Taubah:122)

Dalam kerangka bisnis, keterampilan yang dibutuhkan adalah segala hal yang menunjang keberhasilan bisnis. Antara lain, keterampilan dalam mengelola keuangan (manajemen keuangan), keterampilan atau keahlian memasarkan (manajemen pemasaran), serta penguasaan keterampilan operasi/ produksi dari lapangan bisnis yang digelutinya. Dengan demikian, penguasaan keterampilan tidak saja menjadi unsur penting bagi pebisnis, namun menjadi kewajiban yang harus dikerjakan oleh sebagian umat apabila ilmu-ilmu tersebut dinilai sangat dibutuhkan umat.

\section{ASPEK PERPAJAKAN DALAM KEPEMILIKAN NPWP PRIBADI}

Berdasarkan Undang-Undang no 6 tahun 1983 tentang ketentuan umum dan tatacara perpajakan, sebagaimana terakhir telah diubah dengan UndangUndang no 28 tahun 2007, terdapat kewajiban bagi pengusaha adalah sebagai berikut:

1) Mendaftarkan diri ke KPP untuk memperoleh NPWP.

Nomor Pokok Wajib Pajak (NPWP) adalah suatu sarana dalam administrasi perpajakan yang dipergunakan sebagai tanda pengenal diri atau identitas Wajib Pajak, oleh karena itu kepada setiap Wajib Pajak hanya diberikan satu Nomor Pokok Wajib Pajak. Selain itu, NPWP juga dipergunakan untuk menjaga ketertiban dalam pembayaran pajak dan dalam pengawasan administrasi perpajakan. Dalam hal berhubungan dengan dokumen perpajakan, Wajib Pajak diwajibkan mencantumkan NPWP yang dimilikinya. 
2) Wajib melaporkan usahanya untuk dikukuhkan menjadi Pengusaha Kena Pajak.

Setiap Wajib Pajak sebagai Pengusaha yang memenuhi syarat untuk dikenakan pajak berdasarkan Undang-undang PPN, wajib melaporkan usahanya untuk dikukuhkan menjadi Pengusaha Kena Pajak (PKP). Fungsi pengukuhan Pengusaha Kena Pajak selain dipergunakan untuk mengetahui identitas Pengusaha Kena Pajak yang sebenarnya, juga berguna untuk melaksanakan hak dan kewajiban di bidang PPN dan Pajak Penjualan Atas Barang Mewah (PPn BM) serta untuk pengawasan administrasi perpajakan.

3) Wajib Mengambil sendiri Surat Pemberitahuan di tempat yang ditetapkan oleh Direktur Jenderal Pajak

Dalam rangka pelayanan dan kemudahan bagi Wajib Pajak, formulir Surat Pemberitahuan disediakan pada kantor-kantor di lingkungan DJP dan tempattempat lain yang ditentukan oleh Direktur Jenderal Pajak yang diperkirakan mudah terjangkau oleh Wajib Pajak.

4) Wajib Pajak wajib mengisi dan menyampaikan Surat Pemberitahuan dengan benar, lengkap, jelas, dan menandatanganinya.

Setiap Wajib Pajak wajib mengisi Surat Pemberitahuan dalam bahasa Indonesia dengan menggunakan huruf Latin, angka Arab, satuan mata uang Rupiah, dan menandatangani serta menyampaikannya ke kantor pelayanan pajak tempat Wajib Pajak terdaftar atau dikukuhkan. Bagi Wajib Pajak yang telah mendapat izin Menteri Keuangan untuk menyelenggarakan pembukuan dengan menggunakan bahasa asing dan mata uang selain Rupiah, wajib menyampaikan Surat Pemberitahuan dalam bahasa Indonesia dan mata uang selain Rupiah yang diizinkan.

5) Wajib membayar atau menyetor pajak yang terutang di kas negara.

Setiap Wajib Pajak dapat membayar atau menyetor melalui Kantor Pos dan atau Bank Persepsi dengan menggunakan Surat Setoran Pajak (SSP). Setiap Wajib Pajak wajib membayar pajak yang terutang berdasarkan ketentuan peraturan perundang-undangan perpajakan, dengan tidak menggantungkan pada adanya surat ketetapan pajak. 
6) Wajib menyelenggarakan pembukuan atau pencatatan.

Bagi Wajib Pajak orang pribadi yang melakukan kegiatan usaha atau pekerjaan bebas dan Wajib Pajak badan di Indonesia diwajibkan untuk menyelenggarakan pembukuan. Dikecualikan dari kewajiban pembukuan, tetapi diwajibkan melakukan pencatatan bagi Wajib Pajak orang pribadi yang melakukan kegiatan usaha atau pekerjaan bebas yang menurut ketentuan peraturan perundang-undangan perpajakan diperbolehkan menghitung penghasilan neto dengan menggunakan Norma Penghitungan Penghasilan Neto dan Wajib Pajak orang pribadi yang tidak melakukan kegiatan usaha atau pekerjaan bebas. Pembukuan dan dokumen-dokumen yang berhubungan dengan kegiatan usaha harus disimpan oleh wajib pajak selama 10 (sepuluh) tahun. Karena selama jangka waktu tersebut DJP masih dapat melakukan pemeriksaan (PER-4/PJ/2009).

7) Dalam hal terjadi pemeriksaan pajak, Wajib Pajak wajib: (a) Memperlihatkan dan atau meminjamkan buku atau catatan, dokumen yang menjadi dasarnya dan dokumen lain yang berhubungan dengan penghasilan yang diperoleh, kegiatan usaha, pekerjaan bebas Wajib Pajak, atau objek yang terutang pajak; (b) Memberikan kesempatan untuk memasuki tempat atau ruang yang dipandang perlu dan memberi bantuan guna kelancaran pemeriksaan; dan (c) Memberikan keterangan yang diperlukan.

\section{Hak Wajib Pajak}

Berdasarkan undang-undang no 6 tahun 1983 tentang ketentuan umum dan tatacara perpajakan, sebagaimana terakhir telah diubah dengan undang-undang no 28 tahun 2007, terdapat hak wajib pajak sebagai berikut:

1) Wajib Pajak berhak untuk menerima tanda bukti pelaporan SPT.

Untuk Surat Pemberitahuan yang disampaikan dengan pos tercatat melalui kantor pos dan giro, maka tanggal pegiriman dianggap sebagai tanggal penerimaan.

2) Wajib Pajak berhak untuk mengajukan permohonan penundaan penyampaian SPT.

Apabila Wajib Pajak ternyata tidak dapat menyampaikan atau menyiapkan laporan keuangan tahunan atau neraca perusahaan beserta laporan laba rugi 
dalam jangka waktu yang telah ditetapkan karena luasnya kegiatan usaha dan masalah-masalah teknis penyusunan laporan keuangan, sulit untuk memenuhi batas waktu penyelesaian dan memerlukan kelonggaran dari batas waktu yang telah ditentukan, Wajib Pajak dapat mengajukan permohonan agar memperoleh perpanjangan waktu penyampaian Surat Pemberitahuan Tahunan Pajak Penghasilan. Perpanjangan jangka waktu penyampaian Surat Pemberitahuan Tahunan Pajak Penghasilan hanya dapat diberikan paling lama 6 (enam) bulan.

3) Wajib Pajak berhak untuk membetulkan Surat Pemberitahuan yang telah disampaikan ke KPP.

Terhadap kekeliruan dalam pengisian Surat Pemberitahuan yang dibuat oleh Wajib Pajak, masih terbuka baginya hak untuk melakukan pembetulan atas kemauan sendiri dalam jangka waktu 2 (dua) tahun sesudah berakhirnya Masa Pajak, Bagian Tahun Pajak atau Tahun Pajak, dengan syarat Direktur Jenderal Pajak belum mulai melakukan tindakan pemeriksaan.

4) Wajib Pajak dapat untuk mengajukan permohonan penundaan dan permohonan untuk mengangsur pembayaran pajak sesuai dengan kemampuannya.

Atas permohonan Wajib Pajak, Direktur Jenderal Pajak dapat memberikan persetujuan untuk mengangsur atau menunda pembayaran pajak yang terutang termasuk kekurangan pembayaran Pajak Penghasilan yang masih harus dibayar dalam Surat Pemberitahuan Tahunan Pajak Penghasilan, meskipun tanggal jatuh tempo pembayaran telah ditentukan. Kelonggaran tersebut diberikan dengan hati-hati untuk paling lama 12 (dua belas) bulan dan terbatas kepada Wajib Pajak yang benar-benar sedang mengalami kesulitan likuiditas.

5) Wajib Pajak berhak untuk mengajukan permohonan penurunan angsuran $\mathrm{PPh}$ Pasal 25.

6) Wajib pajak berhak untuk mengajukan permohonan pengembalian kelebihan pembayaran pajak (melakukan restitusi) .

7) Wajib Pajak berhak untuk mengajukan permohonan pembetulan salah tulis atau salah hitung atau kekeliruan yang terdapat dalam Surat Ketetapan Pajak. 
8) Wajib Pajak berhak untuk mengajukan keberatan atas Surat Ketetapan Pajak dan memperoleh kepastian terbitnya keputusan atas surat keberatannya. Wajib Pajak dapat mengajukan keberatan hanya kepada Direktur Jenderal Pajak atas suatu: (a) Surat Ketetapan Pajak Kurang Bayar; (b) Surat Ketetapan Pajak Kurang Bayar Tambahan; (c) Surat Ketetapan Pajak Lebih Bayar; (d) Surat Ketetapan Pajak Nihil; (e) Pemotongan atau pemungutan oleh pihak ketiga berdasarkan ketentuan peraturan perundang-undangan perpajakan.

Keberatan diajukan secara tertulis dalam bahasa Indonesia dengan mengemukakan jumlah pajak yang terutang atau jumlah pajak yang dipotong atau dipungut atau jumlah rugi menurut penghitungan Wajib Pajak dengan disertai alasan-alasan yang jelas dalam jangka waktu 3 bulan sejak tanggal surat ketetapan pajak yang diajukan keberatan

9) Wajib Pajak berhak mengajukan banding ke pengadilan pajak atas keputusan keberatan yang diterbitkan oleh Direktur Jenderal Pajak.

10) Wajib Pajak berhak untuk mengajukan permohonan penghapusan atau pengurangan pengenaan sanksi perpajakan serta pembetulan ketetapan pajak yang salah atau keliru.

11) Wajib Pajak berhak memberikan kuasa khusus kepada orang lain yang dipercayainya untuk mewakilinya dalam melaksanakan hak dan kewajiban perpajakannya.

\section{WPOP yang Melakukan Kegiatan Usaha/ Pekerjaan Bebas}

Wajib Pajak Orang Pribadi (WPOP) yang melakukan kegiatan usaha/pekerjaan bebas selaku pemberi kerja selain diwajibkan untuk membayar dan melaporkan pajak yang terutang atas penghasilan yang diterima atau diperolehnya sendiri juga diwajibkan untuk menyetorkan dan melaporkan PPh yang terutang atas penghasilan yang dibayarkan atau terutang kepada karyawannya.

Dalam hal WPOP yang melakukan kegiatan usaha/pekerjaan bebas telah dikukuhkan sebagai Pengusaha kena pajak juga memiliki kewajiban dibidang PPN. Bagi Wajib Pajak Orang Pribadi tertentu yang telah ditunjuk oleh Dirjen Pajak sebagai pemotong PPh Pasal 23 dan PPh Final pasal 4 (2), juga memiliki kewajiban dibidang PPh 23 dan PPh Final Pasal 4 (2). 
Kewajiban yang harus dipenuhi oleh WPOP yang melakukan kegiatan usaha/pekerjaan bebas setelah memperoleh NPWP adalah sebagai berikut :

1) Menyampaikan Surat Pemberitahuan Masa (SPT Masa)

Setelah wajib pajak terdaftar di KPP dan memiliki NPWP, maka memiliki kewajiban untuk menyampaikan Surat Pemberitahuan Masa/ bulanan ke kantor pelayanan pajak tempat wajib pajak terdaftar. Jenis SPT Masa yang harus disampaikan oleh wajib pajak Orang Pribadi yang melakukan kegiatan usaha/pekerjaan bebas terdiri dari :

a. SPT Masa PPh Pasal 25

PPh Pasal 25 merupakan angsuran PPh dalam tahun pajak berjalan yang harus dibayar sendiri oleh Wajib Pajak untuk setiap bulan. Besarnya angsuran PPh Pasal 25 adalah sebesar Pajak Penghasilan yang terutang menurut Surat Pemberitahuan Tahunan Pajak Penghasilan tahun pajak yang lalu, setelah dikurangi dengan $\mathrm{PPh}$ yang telah dipotong/dipungut oleh pihak lain dan $\mathrm{PPh}$ yang terutang/dibayar diluar negeri yang dapat dikreditkan; dibagi 12 (dua belas)

b. SPT Masa PPh Pasal 21/26

PPh pasal 21/26 merupakan PPh yang terutang atas penghasilan berupa gaji, upah, honorarium, tunjangan dan pembayaran lain dengan nama dan dalam bentuk apapun sehubungan dengan pekerjaan, jasa atau kegiatan yang dilakukan oleh wajib pajak orang pribadi. Berdasarkan ketentuan Pasal 21 Undang-undang $\mathrm{PPh}, \mathrm{PPh}$ Pasal 21 wajib dipotong, disetor dan dilaporkan oleh pemotong pajak, yaitu : pemberi kerja, bendaharawan pemerintah, dana pensiun, badan, perusahaan dan penyelenggara kegiatan.

c. SPT Masa PPN

Bagi Wajib Pajak yang telah dikukuhkan sebagai Pengusaha Kena Pajak (PKP) diwajibkan untuk memungut Pajak Pertambahan Nilai (PPN) dan Pajak atas Penjualan Barang Mewah (PPn BM) serta menyampaikan SPT Masa PPN. Fungsi Surat Pemberitahuan (SPT PPN) adalah sebagai sarana untuk melaporkan dan mempertanggungjawabkan penghitungan jumlah Pajak PPN dan PPn BM yang sebenarnya terutang dan untuk melaporkan tentang: Pengkreditan Pajak Masukan terhadap Pajak Keluaran; 
Pembayaran atau pelunasan pajak yang telah dilaksanakan sendiri oleh Pengusaha Kena Pajak dan atau melalui pihak lain dalam satu Masa Pajak, yang ditentukan oleh ketentuan peraturan perundang-undangan perpajakan yang berlaku; dan Ketentuan mengenai PPN diatur dalam Undang-undang no 8 tahun 1983 tentang Pajak Pertambahan Nilai Barang dan Jasa dan Pajak Penjualan atas Barang Mewah sebagaimana terakhir telah diubah dengan UU No 18 tahun 2000 beserta peraturan pelaksanaannya.

d. $\quad$ SPT Masa PPh Pasal 23/26

Direktur Jenderal Pajak dapat menunjuk Wajib Pajak orang pribadi dalam negeri sebagai pemotong Pajak Penghasilan Pasal 23. Wajib Pajak Orang Pribadi tertentu tersebut terdiri dari: Akuntan, Arsitek, Dokter, Notaris, Pejabat Pembuat Akte Tanah (PPAT) kecuali PPAT tersebut adalah Camat, pengacara, dan konsultan, yang melakukan pekerjaan bebas; Orang Pribadi yang menjalankan usaha yang menyelenggarakan pembukuan.

e. SPT Masa PPh Final pasal 4 (2) meliputi: (1) PPh final atas penghasilan yang diterima/diperoleh oleh wajib pajak yaitu bagi Wajib Pajak Orang Pribadi yang melakukan kegiatan usaha atau pekerjaan bebas yang memperoleh penghasilan yang merupakan obyek $\mathrm{PPh}$ final, maka diwajibkan untuk membayar dan melaporkan PPh final pasal 4 (2) yang tertuang atas penghasilan tersebut. Jenis penghasilan lain yang merupakan obyek PPh final dan pembayaran PPh-nya wajib dilakukan sendiri oleh penerima penghasilan (Wajib pajak) adalah penghasilan dari pengalihan hak atas tanah dan/atau bangunan; penghasilan dari persewaan tanah dan/atau bangunan; penghasilan dari Usaha Jasa Konstruksi;

(2) $\mathrm{PPh}$ final atas penghasilan yang terutang/dibayarkan kepada pihak lain. Dirjen Pajak dapat menunjuk Wajib pajak Orang Pribadi tertentu sebagai pemotong PPh Final Pasal 4 (2) atas transaksi persewaan Tanah dan atau bangunan. Wajib Pajak Orang Pribadi tertentu yang dapat ditunjuk sebagai pemotong $\mathrm{PPh}$ atas transaksi persewaan tanah dan atau bangunan oleh DJP adalah: Akuntan, arsitek, dokter, Notaris, Pejabat Pembuat Akte Tanah (PPAT) kecuali PPAT tersebut adalah Camat, pengacara, dan konsultan, yang melakukan pekerjaan bebas yang telah terdaftar sebagai Wajib Pajak 
Dalam Negeri; Orang pribadi yang menjalankan usaha yang menyelenggarakan pembukuan yang telah terdaftar sebagai Wajib Pajak dalam negeri. WPOP tertentu yang telah mendapat surat penunjukan sebagai pemotong Pajak atas penghasilan dari persewaan tanah dan atau bangunan dari KPP tempat WP terdaftar memiliki kewajiban untuk memotong, menyetorkan dan melaporkan $\mathrm{PPh}$ final atas penghasilan dari transaksi persewaan tanah dan atau bangunan yang dibayarkan atau terutang kepada pihak lain.

2) Menyampaikan Surat Pemberitahuan Tahunan (SPT Tahunan)

Setelah berakhirnya tahun pajak, Wajib pajak diwajibkan untuk menyampaikan SPT Tahunan (SPT Tahunan PPh Orang Pribadi - SPT 1770). Fungsi Surat Pemberitahuan (SPT Tahunan) bagi Wajib Pajak adalah sebagai sarana untuk melaporkan dan mempertanggungjawabkan penghitungan jumlah pajak yang sebenarnya terutang dan untuk melaporkan tentang pembayaran atau pelunasan pajak yang telah dilaksanakan sendiri dan atau melalui pemotongan atau pemungutan pihak lain dalam 1 (satu) Tahun Pajak atau Bagian Tahun Pajak; penghasilan yang merupakan objek pajak dan atau bukan objek pajak; dan harta dan kewajiban;

\section{PENUTUP}

Bisnis Islami merupakan serangkaian aktivitas bisnis dalam berbagai bentuknya yang tidak dibatasi jumlah (kuantitas) kepemilikan hartanya (barang/jasa) termasuk profitnya, namun dibatasi dalam cara perolehan dan pendayagunaan hartanya (ada aturan halal dan haram). Dalam menjalankan bisnis di Indonesia bagi seorang pebisnis atau pengusaha wajib memenuhi ketentuan umum dan tata cara perpajakan yang berlaku. Pengusaha menurut UU Nomor 28 tahun 2007 tentang Ketentuan Umum dan Tata Cara Perpajakan (KUP) adalah orang pribadi atau badan dalam bentuk apapun yang dalam kegiatan usaha atau pekerjaannya menghasilkan barang, mengimpor barang, mengekspor barang, melakukan usaha perdagangan, memanfaatkan barang tidak berwujud dari luar daerah pabean, melakukan usaha jasa, atau memanfaatkan jasa dari luar daerah pabean. 
Kewajiban ber NPWP sesungguhnya merupakan kewajiban setiap orang pribadi, baik orang pribadi yang melakukan kegiatan usaha atau pekerjaan bebas ataupun yang berstatus pegawai. Berdasarkan undang-undang no 6 tahun 1983 tentang ketentuan umum dan tatacara perpajakan, sebagaimana terakhir telah diubah dengan undang-undang no 28 tahun 2007, terdapat kewajiban wajib pajak sebagai berikut: (1) Mendaftarkan diri ke KPP untuk memperoleh NPWP; (2) Wajib melaporkan usahanya untuk dikukuhkan menjadi Pengusaha Kena Pajak; (3) Mengambil sendiri Surat Pemberitahuan di tempat yang ditetapkan oleh Direktur Jenderal Pajak; (4) Wajib Pajak wajib mengisi dan menyampaikan Surat Pemberitahuan dengan benar, lengkap, jelas, dan menandatanganinya; (5) Wajib membayar atau menyetor pajak yang terutang di kas negara, (6) Wajib menyelenggarakan pembukuan atau pencatatan. Dalam hal terjadi pemeriksaan pajak, Wajib Pajak wajib memperlihatkan dan atau meminjamkan buku atau catatan, dokumen yang menjadi dasarnya dan dokumen lain yang berhubungan dengan penghasilan yang diperoleh, kegiatan usaha, pekerjaan bebas Wajib Pajak, atau objek yang terutang pajak; Memberikan kesempatan untuk memasuki tempat atau ruang yang dipandang perlu dan memberi bantuan guna kelancaran pemeriksaan; Memberikan keterangan yang diperlukan.

Adapun hak wajib pajak adalah wajib pajak berhak untuk menerima tanda bukti pelaporan SPT, Wajib Pajak berhak untuk mengajukan permohonan penundaan penyampaian SPT, Wajib Pajak berhak untuk membetulkan Surat Pemberitahuan yang telah disampaikan ke KPP, Wajib Pajak dapat untuk mengajukan permohonan penundaan dan permohonan untuk mengangsur pembayaran pajak sesuai dengan kemampuannya, Wajib Pajak berhak untuk mengajukan permohonan penurunan angsuran $\mathrm{PPh}$ Pasal 25, Wajib pajak berhak untuk mengajukan permohonan pengembalian kelebihan pembayaran pajak (melakukan restitusi), Wajib Pajak berhak untuk mengajukan permohonan pembetulan salah tulis atau salah hitung atau kekeliruan yang terdapat dalam Surat Ketetapan Pajak, Wajib Pajak berhak untuk mengajukan keberatan atas Surat Ketetapan Pajak dan memperoleh kepastian terbitnya keputusan atas surat keberatannya, Wajib Pajak berhak mengajukan banding ke pengadilan pajak atas keputusan keberatan yang diterbitkan oleh Direktur Jenderal Pajak, Wajib Pajak 
berhak untuk mengajukan permohonan penghapusan atau pengurangan pengenaan sanksi perpajakan serta pembetulan ketetapan pajak yang salah atau keliru, Wajib Pajak berhak memberikan kuasa khusus kepada orang lain yang dipercayainya untuk mewakilinya dalam melaksanakan hak dan kewajiban perpajakannya.

\section{DAFTAR PUSTAKA}

Budianto, Triyani. Ketika Kita harus Mempunyai NPWP. www.triyani.co.id

Gunadi. Panduan Komprehensif Pajak penghasilan. 2001. Jakarta: PT Multi Utama Consultindo.

Hamdan, Deden. 2002. Belajar Berbisnis dari Bengkel Akhlak. Manajemen No.169. September.

Mardiasmo. Perpajakan Edisi Revisi . 2006. Yogyakarta: Penerbit Andi Offset.

Republik Indonesia. Undang-undang No. 28 tahun 2007 tentang perubahan ketiga atas Undang-Undang Nomor 6 Tahun 1983 tentang Ketentuan Umum dan tatacara Perpajakan

Republik Indonesia. Undang-undang No.36 tahun 2008 tentang Perubahan Keempat atas Undang-Undang Nomor 7 Tahun 1983 tentang Pajak Penghasilan

Peraturan Pemerintah. Keputusan Presiden. Keputusan Menteri Keuangan. Keputusan Direktur Jenderal Pajak. dan Surat Edaran Direktur Jenderal Pajak yang berkaitan dengan Undang-Undang Perpajakan tersebut.

Soearsono. 1996. Pengantar Kewiraswastaan. Bogor: Tin-Fateta IPB.

Yusanto, Muhammad Ismail dan Widjajakusuma, Muhammad Karebet. 2002.

Menggagas Bisnis Islami. Jakarta: Gema Insani. 